\title{
Cosmopolitan (Dis)encounters: The Local and the Global in Anthony Minghella's Breaking and Entering and Rachid Bouchareb's London River
}

CAROLINA SÁNCHEZ-PALENCIA

ABSTRACT: Through the postcolonial reading of Breaking and Entering (Anthony Minghella, 2006) and London River (Rachid Bouchareb, 2009), I mean to analyse the multiethnic urban geography of London as the site where the legacies of Empire are confronted on its home ground. In the tradition of filmmakers like Stephen Frears, Ken Loach, Michael Winterbottom or Mike Leigh, who have faithfully documented the city's transformation from an imperial capital to a global cosmopolis, Minghella and Bouchareb demonstrate how the dream of a white, pure, uncontaminated city is presently «out of focus», while simultaneously confirming that colonialism persists under different forms. In both films the city's imperial icons are visually deconstructed and resignified by those on whom the metropolitan meanings were traditionally imposed and now reclaim their legitimate space in the new hybrid and polyglot London. Nevertheless, despite the overwhelming presence of the multicultural rhetoric in contemporary visual culture, their focus is not on the carnival of transcultural consumption where questions of class, power and authority conveniently seem to disappear, but on the troubled lives of its agents, who experience the materially local urban reality as inevitably conditioned by the global forces -international war on terror, media coverage, black market, immigration mafias, corporate business- that transcend the local. This paradox is also perceived in the way the two filmmakers depict the postcolonial metropolis as the locus of social inequality and disequilibrium, but also as the scenario of unexpected encounters and alliances where both the protagonists and the spectators can explore the fantasies and fears about Otherness, and thus contest racial stereotypes

Keywords: postcolonial cinema, urban studies, globalization, multiculturalism, otherness. 
RESUMEN: Mediante una lectura postcolonial de Breaking and Entering (Anthony Minghella, 2006) y London River (Rachid Bouchareb, 2009) trato de analizar la geografía multiétnica de Londres como el espacio desde donde interrogar el legado del Imperio desde el lugar mismo en que este se originó. En la tradición de directores como Stephen Frears, Ken Loach, Michael Winterbottom o Mike Leigh, que han documentado fielmente la transformación de esta ciudad desde la capital imperial a la cosmópolis global, Minghella y Bouchareb demuestran que el sueño de una ciudad blanca, pura y no contaminada es irrealizable, constatando, al mismo tiempo, la pervivencia del colonialismo bajo diferentes facetas. En ambas películas, la iconografía imperial de la ciudad es visualmente reconstruida y resignificada precisamente por aquellos sujetos sobre los que tradicionalmente se han impuesto los significados de la metrópolis, los mismos que ahora reclaman un espacio legítimo en la nueva Londres híbrida y políglota. No obstante, y pese a la apabullante presencia de esta retórica de lo multicultural en la cultura visual contemporánea, el objeto de estos directores no es el carnaval transcultural de la ciudad donde las cuestiones de clase, poder y autoridad parecen haber desaparecido, sino la existencia conflictiva de sus habitantes, que experimentan la realidad cotidiana como inevitablemente condicionada por fenómenos globales - guerra contra el terrorismo, medios de comunicación, mercado negro, inmigración ilegal, economía multinacional- que transcienden la materialidad de lo local. Esta paradoja también se percibe en el modo en que los dos directores conciben la metrópolis postcolonial como lugar de desigualdades y desequilibrios, pero también como el escenario de encuentros y alianzas inesperadas donde protagonistas y espectadores pueden explorar las fantasías sobre el Otro y cuestionar los estereotipos raciales.

Palabras clave: cine postcolonial, urbanismo, globalización, multiculturalismo, otredad.

It is a truism that cinema is eminently an urban cultural form and, as such, it has not ceased - since its origins - to draw the modern and postmodern cartographies of the city both in its spatial and social complexities. But the alltoo-evident nexus cinema/city has been recently refocused under the lens of postcolonial theory, thus offering in the last twenty years visual evidence of the dual characterization of the city that the UNESCO assumes: on the one hand, a site of multicultural encounters, of assimilation and citizenship; on the other hand, a site of isolation, misery, violence and human exploitation. Far too often the profit-oriented promotion of the former has served to ignore the harsh realities of the latter. 
London has been consistently filmed in glamorous and idyllic vignettes that can be related to what Paul Gilroy (1999: 57) has described as «fantasies of return to the imaginary homogeneity of past whiteness and the restoration of Europe's imperial status». ${ }^{1}$ But it has also been viewed as the former seat of Empire now exhibiting radical changes derived from the collapse of the colonial system. Such is the approach of Anthony Minghella in Breaking and Entering (2006) and Rachid Bouchareb in London River (2009), two films that demonstrate how the dream of a white, pure, uncontaminated city is presently "out of focus», while simultaneously confirming that colonialism persists under metamorphosed forms. In the vein of filmmakers like Stephen Frears, Ken Loach, Neil Jordan, Michael Winterbottom or Mike Leigh among others, Minghella and Bouchareb coincide in their delineation of textured images of immigrant poverty in a city not commonly depicted for it, and in their examination of prejudice, intolerance and paranoid fear towards the non-white community as neo-colonial practice in contemporary Europe. ${ }^{2}$

The post-colonial condition of cities is often examined in relation to those countries or contexts that were formally colonized in the recent past-cities like Casablanca, Tunis, Lagos, Dakar, Delhi, Jakarta, Kinshasa or Singapore, among others. But postcolonial theory also attends to Western or Northern metropolises that were former imperial centres, and explores the transformations resulting from their colonial and postcolonial experiences. Such examinations imply a fundamental readjustment in the postcolonial critical focus inasmuch as they consider postcoloniality to be a phenomenon as much evident in the formerly colonized context as in the former colonizer's one. I will draw from what has already become a solid tradition by taking London as the epitome of these new postcolonial metropolises, no longer a place of departure (as in most colonial

1. Woody Allen's Match Point (2005), Scoop (2006) and Cassandra's Dream (2007); Peter Howitt's Sliding Doors (1998); Mike Newell's Four Weddings and a Funeral (1994); Roger Michell's Notting Hill (1999); Richard Curtis' Love Actually (2003); Mike Nichols' Closer (2005); Sharon Maguire's Bridget Jones 's Diary (2001) and Beeban Kidron's Bridget Jones: The Edge of Reason (2004) are just but a few recent London-set films in which the city is reduced to a socially and racially homogeneous backdrop against which conservative narratives of class and gender are played out in a sort of nostalgic urban pastoral.

2. Films like Stephen Frears's My Beautiful Launderette (1985), Sammy and Rose Get Laid (1987) and Dirty Pretty Things (2002); Michael Winterbottom's Wonderland (1999) and In this World (2002); Mike Leigh's High Hopes (1988) and Secrets and Lies (2000); Neil Jordan's Mona Lisa (1986) and Breakfast on Pluto (2005); and Ken Loach's It's a Free World (2002) or Ae Fond Kiss (2004), many of which have successfully moved from independent to mainstream circuits, can be included in this canon. These directors, explicitly nourished within the tradition of British social realism, coincide in portraying the rise and fall of British multiculturalism by highlighting controversial issues of cultural identity, racial stereotyping, hybridity and belonging. 
narratives) but a place of destination, because, together with Simon Gikandi (1996: 27), I firmly believe that «the task of decolonization must be taken to the metropolis itself; [that] the imperial mythology has to be confronted on its home ground». This interest in redefining London from a postcolonial perspective is evidenced by the recent surge of books on migrant or diasporic London writing: Sukhdev Sandu's London Calling: How Black and Asian Writers Imagined a City (2003); John Clement Ball's Imagining London: Postcolonial Fiction and the Transnational Metropolis (2004) and John McLeod's, Postcolonial London: Rewriting the Metropolis (2004) are instances of this critical attempt at depicting the Caribbean (David Dabydeen, Fred D'Aguiar, Caryl Philips, Bernardaine Evaristo, Grace Nichols, Zadie Smith, Andrea Levy), South Asian (Salman Rushdie, Anita Desai, Hanif Kureishi, Monica Ali), African (Buchi Echemeta, Ben Okri, Tsitsi Dangarembga, Zoë Wicomb) and Canadian (Susan Swan, Robertson Davies, Margaret Atwood, Mordecai Richler) literary interaction with London, a contested space between different minority ethnic groups and the white British majority. While these authors (and much of the canon of postcolonial London writing they analyze) tend to celebrate the cosmopolitan status of a city which has been repeatedly said to «contain the whole world within itself», their attention is always drawn towards the continuities and legacies of Empire as they consistently use London to interrogate the limits of contemporary British identity.

In the light of these debates, it is not difficult to observe in these two films a number of images in which the city's imperial icons -like Buckingham Palace, Primrose Hill, St. Pancras or King's Cross- and its shorthand imagery of red buses and black taxis are visually deconstructed and resignified. Just as many postcolonial novels using European capitals as their setting and mythical place are determined by disillusion and detachment, by the traumatic encounter with a place which has no resemblance at all with the «promised land» envisioned by the colonial subjects, the postcolonial city featured in these films is reappropriated and reinvented by those on whom the metropolitan meanings were traditionally imposed. Against the romantic idealization of the metropolis undergone by imperial fictions, postcolonial texts reveal that «the socially and economically oppressive spaces England constructed in faraway lands are, in essence, reproduced in the (post)imperial metropolis» (Ball, 2004: 6). But, to put it into poststructuralist terms, this reappropriation would be «a repetition with a difference», because, as is well known, postcolonialism does not involve a mere reproduction and/or inversion of the colonial categories, but rather a blurring of boundaries in which the clear-cut binaries of the imperial discourse -center/periphery; colonizer/colonized; metropolis/colony; First World/Third World- are replaced by the language of diaspora, hybridity, multiculturalism and globalization. 
And yet, despite the overwhelming presence of this new rhetoric in contemporary visual culture, neither Minghella nor Bouchareb is easily seduced by its sirens' songs, as they both consistently avoid the thoughtless romantization of migration and settlement. Their focus is not on the carnival of transcultural consumption where questions of class, power and authority conveniently seem to disappear, but on the troubled lives of its producers, lending attentive ears to the explicitly unequal power relations to which the global and the postcolonial are inevitably associated.

Paul Gilroy (1999: 67) has warned us of the perils of exoticism by relating this phenomenon to «a situation in which glamorous and unfamiliar cultures can be consumed in the absence of any face-to-face recognition or real-time negotiations with their actual creators», a situation in which national and ethnic differences are flagrantly colonized and commercialized. In a similar vein, the Senegalese writer Catherine N'Diaye (1984: 13) regards exoticism as a sort of anti-knowledge of the Other, in its reluctance to solve the enigma, to reduce the distance, to lift the veil, in its easily falling into folklore, into generalized and fixed meanings.

Echoing these arguments, the two filmmakers try to transcend the pseudoanthropological gaze and search instead deep inside the heart of multicultural cities, within their conflicts and divisions, thus resisting the commercial allure of the exotic and the sugar-coated version of multiculturalism.

After all, the postcolonial cinema produced by Bouchareb and Minghella cannot be considered as a rigid category distinguished by axiomatic features, ${ }^{3}$ but as an optic through which to address questions of postcolonial history, geography and subjectivity; an optic which enables them to engage the tense asymmetries generated by immigration, economic exploitation, globalization, racial and religious conflict, issues of citizenship, cultural self-representation and other current circumstances which are deeply rooted in colonial, postcolonial, and neocolonial scenarios.

In Breaking and Entering, Anthony Minghella juxtaposes two contrasting versions of London: on the one hand, the imagined, ideal city designed by the architect Will Francis in his dream-like project to transform King's Cross area; on the other hand, the real, lived city of the young Kosovan refugee Miro who breaks into the local offices for petty burglary. These different visions of the city

3. Sarita Malik (2002: 64) summarises the characteristics of what she calls Third Cinema as «formal innovation, a break with an individual protagonist and conventional narrative, its connection to active liberation struggles, its invitation to the spectator/viewer as participant or comrade, its collective production process, and its opening up of dialogue between filmmakers and theorists»; a narrow focus that, in my opinion, problematizes its application to much of the British multicultural and postcolonial filmography. 
are reminiscent of the distinction formulated by Mazierska and Rascaroli (2003: 2) between the «real city» - permanently sited and described by its map- and the «city-text»-the mutating product of countless and intermingled instances of representation-. The overlapping of these distinct analytical perspectives creates an ever-shifting urban map that Iain Chambers describes as disturbingly vibrant and complex but worth assuming when dealing with cinematic representations of the city:

Here we find ourselves in the gendered city, the city of ethnicities, the territories of different social groups, shifting centers and peripheries -the city that is a fixed object of design (architecture, commerce, urban planning, state administration) and yet simultaneously plastic and mutable: the site of transitory events, movements, memories. This is therefore also a significant space for analysis, critical thought and understanding. (Chambers, 1994: 92-93)

Will and his partner's goal is to gentrify a neighborhood distinguished by recent immigration, prostitution and crime, through master planned architectural development. ${ }^{4}$ The opening scenes offer an interesting travelling shot of the district's inassimilable contrasts, which are emphatically underlined by police detective Bruno Fella in his over-pragmatic remark: "You know what your problem is, Sandy? King's Cross. That's you there. You've got the British Library over there with Eurostar, and bang in the middle you got crack village, with a load of Somalians walking about with machetes. It's an area in flux!». This «area in flux» is the common space two different groups of people have to share and negotiate in the course of a regeneration process which, as Tom Slater argues, is wholly determined by economic, social and ethnic aspects:

Gentrification commonly occurs in urban areas where prior disinvestment in the urban infrastructure creates opportunities for profitable redevelopment, where the needs and concerns of business and policy elites are met at the expense of urban

4. The area surrounding King's Cross Station has traditionally had a reputation as the «red light district» after dark. But with the arrival of the Eurostar at the nearby St Pancras International, the neighbourhood has become an example of urban «gentrification». The term was coined by sociologist Ruth Glass in 1964 and it basically refers to the changes derived from the displacement of working-class occupiers by middle and upper class incomers who transform certain districts by creating exclusive urban environments to serve the needs of capital accumulation at the expense of the social needs of home, community and family. Although the term has been conveniently assimilated by developers, politicians, and financiers in their discourse about residential rehabilitation and metropolitan regeneration, most social critics agree that Glass's original meaning should not be obviated because it explicitly captures the social inequalities generated by capitalist urban land markets and policies (Slater, 2001: 571). 
residents affected by work instability, unemployment, and stigmatization. (Slater, 2011: 572)

It is very significant that a futuristic scale model of this virtual eco-friendly community occupies the center of Will's office like a shrine, and that the old colonial discourse about efficacy and self-legitimating ethics resonates in the rhetoric of the project's promotional video. ${ }^{5}$ But their visionary design is constantly thwarted by night burglaries where computers and electronics are stolen, thus entering the circuit of black market and illicit trade. When Will surprises the teenage burglar one night, he chases him back to the housing complex where he lives with his Bosnian mother, the cement blocks of Alexandra Road, which offer a blunt contrast to the architect's glass and steel chic apartment. When Will meets Amira, the two embark on an affair with very explicit melodramatic overtones, burdened by secrets, mistrust, betrayal, and ultimately, compromise, because the burglary is really just the jumping-off point for a story about miscommunication where all of the characters seem to have barriers among them, be they emotional, linguistic, or cultural, and the urban space is the social and architectural site where to stage them.

Will and Miro represent two very different ways of occupying the cityscape: Will's implies abstraction, control and detachment from the real experience of the city, a lack of commitment that is underlined in a climactic speech, «I don't even know how to be honest anymore. Maybe that's why I like metaphors». Miro's is essentially a subversion of the urban space articulated through the practice of parkour, a physical discipline which is also a form of urban activism, consisting in overcoming obstacles by vaulting, rolling, running, climbing, and jumping. If, in a sort of neo-colonial act, Will tries to create «space» by cleaning up the city, neatly delineating its contours, but -as in his unhappy family life- evading real engagement, Miro's running body and his view of the city from the rooftops, as if alienated from Will's megaproject, offer, as Bird \& Luka (2010: 89) argue, physical and ideological resistance to the limitations of the modern metropolis. The constantly shifting urban geography portrayed by Minghella is thus one of

5. Minghella's notion that there are powerful ideological imperatives behind the work of architects, urban designers and planners seems to challenge certain political-economic explanations of gentrification that focus too narrowly on cycles of investment and market fluctuations of urban land rent and tend to minimise the importance of human agency. As Damaris Rose (1984: 56) puts it, «Gentrifiers are not the mere bearers of a process determined independently of them. Their constitution, as certain types of workers and as people, is as crucial an element in the production of gentrification as is the production of the dwellings they occupy». 
inexhaustible human, cultural and architectural variety, one which cannot be contained within the homogenizing design of Will's firm, but lets us see beauty in building sites, alleyways, community centers, council apartments and what has been termed as «in-between, interstitial space[s]» (Ball, 2004: 79, 219), that are very helpful to question comfortable notions of home, nation and history, and to symbolize problematic notions of diasporic unbelonging, exclusion and cultural alienation. Facing urban images like these, the spectator becomes immediately aware that the London depicted here is not a bourgeois fantasy, a tourist's dream, or the 2012 Olympic Games magnificent venue, but, in a typically Dickensian fashion, its rough and filthy underbelly, that is, a workaday city full of day laborers (Amira makes a precarious living as a seamstress), illegal immigrants and asylum seekers. This is the multi-ethnic setting where Cool Britannia is confronted by «the new kids on the block», the immigrant community from Eastern Europe; a setting where, as in Jazmin Dizdar's Beautiful People (1998), another film dramatizing the British encounter with the Balkan communities, the chaotic fragmentation of urban environment can be interpreted as deriving from a prior dismemberment: that of postcommunist Yugoslavia, whose refugees bring to multicultural London pieces of their former lives thus contributing to the effect of plurality and fragmentation (Mazierska \& Rascaroli, 2003: 185).

In Rachid Bouchareb's London River the terror attacks of $7^{\text {th }}$ of July 2005, where 52 commuters were killed and over 700 injured by four bombs on the London mass transit system, are taken as the backdrop for the human drama of two very different characters who have both travelled to London in search of their missing children. The protagonists of this chronicle of miscommunication are solitary, tragedy-stricken flâneurs in whom the fragmented images, meanings and symbols of the postmodern (and post-mortem!) urban space converge. Although Bouchareb recreates a very explicit post-traumatic scenario, he does not employ the chaotic, experimental and non-linear structures commonly depicted in most post-traumatic texts, thus challenging the belief (which has become almost axiomatic within Trauma Studies) that this sort of experiences can only be adequately represented through a disjointed and anti-narrative aesthetics that mimics the psychic effects of trauma. His is a realistic rendering of the post-bombing anxiety experienced by many anonymous citizens, waiting for news and fearing the worst. ${ }^{6}$

6. Charlotte Brunsdon, author of London in Cinema (2007), explains in an interview that she chose to begin her book at the end of the Second World War because the imagery of the London bombings is very resonant in the representation of the city. Bomb-sites often provide a shocking reversal of private and public, with formerly interior bedroom walls standing naked to the streets, and the shape of roads, or blocks of flats abruptly transformed by gaping absences. The bombsites of London dominated the cityscape long after the war, recurring in cinema, 
Elizabeth is a white Christian widow of a Falklands war veteran whose daughter has moved from her quiet home in Guernsey to study in the capital. Ousmane is a French resident black Muslim who is looking for the son he has not seen in years, and who wants to bring him home to Mali to reunite their split family. A prisoner of her own prejudices, she eyes him with suspicion and paranoid feelings, just as she looks at every Muslim as a potential threat: «The place is crawling with Muslims», she cries to her brother on the phone when she arrives at the area of London her daughter was staying in, the multi-ethnic Finsbury Park neighborhood, over a halal shop. But Elizabeth's fears are only an eloquent «sign of the times», because, as most observers have concluded, the London bombings, along with attacks in New York, Washington DC and Madrid, shifted attitudes towards Muslims in Western Europe (Abbas, 2005; Kelly and Street, 2009); and the fact that the terrorists were all British citizens, that is homegrown, accentuated the public concern about the integration of resident Muslims who became the easy target of increased racial and religious prejudice. Her confusion and apprehensions for her daughter's whereabouts get aggravated by her own incomprehension of this strange foreign environment that is far from the image she had of Jane's life; and when she learns that her daughter, her "white English rose», was attending the local mosque to take lessons in Arabic language she feels completely puzzled and asks «But who speaks Arabic»? It seems that Elizabeth is far more an outsider in postcolonial London than Ousmane, and her unease and deep seated mistrust intensify when she comes to realise that her daughter may have been cohabiting with a Muslim, Ousmane's missing son.

To a great extent, her fears (of Arabic language, of the Muslim community, of the halal shop and the Finsbury mosque) echo the national anxieties about the limits of English identity, threatened by the unavoidable (yet often unwanted) contact with the Other. But, curiously enough, her sense of loss, vulnerability and disempowerment takes place in the very site, London, from which power once flowed (out from the core to the periphery); which could be interpreted as an interesting inversion of the traditional colonial narrative. After all, in the colonial/ imperial fictions the civilized subject (usually White) embarks on a mythical

literature, letters and painting. However, in contrast to the way in which these desolate ruins are figured in the cinema of continental Europe, in British cinema these ruins can symbolise optimism and the possibility of a better world for the children who play there. $<\mathrm{http}: / / 25 \mathrm{fps}$. $\mathrm{cz} / 2012 /$ cinematic-london>.

Bouchareb's emphasis is more on the emotional than on the architectural devastation of the city, and the ruins he exhibits are those of the protagonists' torn family lives, but London River shares with many post-war films, such as Waterloo Road (1945), Passport to Pimlico (1949) and Mandy (1952), this touch of a healing narrative of survival and the optimistic belief in a better future. 
journey and departs from a place of safety and civilization into the «heart of darkness» where he is to fulfil his mission; but here the «heart of darkness» is the metropolis itself. Elizabeth is depicted as a nostalgic representative of Empire who loses command of her own national identity. But she reverses the conventional colonial and postcolonial narratives in some other ways too. By re-writing, for instance, the story of the Commonwealth immigrant who arrives in the metropolis and feels the hostile and discriminating gaze of the white onlookers. Here she is the Other, the Alien, and this makes us realize that racial and cultural exclusion can be entirely a matter of perspective. Generationally, too: most postcolonial authors centre their narratives on young urban people, being their parents either absent or misrepresented. It seems that metropolitan belonging (no matter how precarious, protean and provisional) is with the young. But here, as in Minghella's film, the challenge is for the older generation, who are united not only by the sense of loss they share, but by the terrible realisation that neither of them really knew their children as well as they should have done. The relationships between parent and child have been allowed to drift away, and London River has a core of sadness and regret about this lost connection that is evoked by the metaphor of the extinguishing elm trees that Ousmane guards as a forestry worker in France. Shot with a hand-held camera and on a low budget, the film produces a kitchen-sink effect, which, together with the subtle, under-stated performances from the two leading actors, adds a documentary-style realism to this inquiry into the relationships between the local and the global, the rural and the urban, the private and the public spaces.

Whereas Minghella's film opens with the image of a busy construction site depicting King's Cross as «an area in flux», Bouchareb's opens with an inspiring view of Elizabeth's idyllic and peaceful farmhouse in Guernsey, conjuring up a genuinely English landscape and sensibility; a mystical Englishness that is soon confronted by the multiethnic, noisy and fragmented cityscape of Northern London. At this point I would like to recall McLeod's (2004: 17) conceptualization of the city as the primary location of multiethnic Britishness: «the perils of transcultural ex-centricity are safely contained within the cordon sanitaire of urban limits, beyond which conventional models of Englishness remain untouched». Through Elizabeth's fearful and biased gaze, Bouchareb confronts the spectator with the deep-seated association between black life and the chaos and danger of urban settings; and this is the starting point for the film's examination of prejudice and ignorance about the Other, be it a generational, cultural, religious or racial Other. ${ }^{7}$

7. The Algerian-born Rachid Bouchareb anticipates the analysis of prejudice and discrimination in his film Days of Glory (2007), an interesting insight into the treatment of the North African 
But Elizabeth and Ousmane will have to overcome their initial bias and hostility, as they literally have to walk the same urban geography, from police station, to hospitals and morgues until they gradually realise that they have more in common than it would seem at first: their children were in a relationship and were both killed in the bombings. The fact that Muslims were also counted as victims (and not only as the perpetrators) of the attacks dismantles the discourse behind much of the media coverage of this event, which tended to associate «terrorists» with «Muslims», thus moving public opinion towards discriminatory attitudes and perceptions.

In both films the interplay between the global and the local is given a significant twist that is worth discussing, as it helps delineate the social conflicts that constitute city life. ${ }^{8}$ Their characters experience the materially local urban reality which at the same time is inevitably conditioned by the global forces (international war on terror, media coverage, corporate business, black market, immigration mafias) that transcend the local. The individual stories narrated by Bouchareb and Minghella demonstrate that the local cannot disappear under the pressure of the global, and that the city is to all extents and purposes physically and locally lived in. Contesting the comforting rhetoric of developers, designers and politicians, their urban representations pay attention instead to global population who are simultaneously displaced from their motherlands and deprived of a legitimate space in the metropolis where they become extremely vulnerable and breakable.

Seen in this light, the two films contradict the views of globalization as an equalizing phenomenon by showing that the flows of people, information and capital are immensely uneven. They demonstrate that in the postcolonial city differences in class usually manifest themselves in a racialized form, and that racial diversity and the contextual specificities of each community dismantle any

soldiers who fought heroically to liberate France during the Second World War, but were then considered as second-class citizens by an ungrateful French Administration and a strongly biased public opinion.

8. The image of London as the site of the complex interaction between the global and the local was reinforced by film director Danny Boyle in his pageant for the Olympic Games opening ceremony on July $27^{\text {th }} 2012$. While celebrating the social and racial mobility of contemporary Britain, and the nation's tradition of protest and dissent, Boyle's spectacle fell -albeit irreverently- into the nostalgic shared iconography of the National Health Service and monarchy, of pop-music and Shakespeare, James Bond and the Industrial Revolution. Marina Hyde, one of the many commentators of the event, makes an interesting point by comparing London 2012 with Beijing 2008: «An architect of Beijing's ceremony once said that event had served Chinese food for the foreign palate, but Danny Boyle's banquet felt as deliciously indigestible to global tastes as Marmite or jellied eels» (The Guardian, Saturday 28 July, 2012). 
homogenizing theories about African, Asian and Eastern European diasporas, thus proving that «race» is no guarantee for solidarity.

At this point, and as I am heading to the end of this paper, I would like to recall UNESCO's dual characterization of the city with which I opened my discussion: on the one hand, it is a site of encounters, of cultural exchange and belonging; on the other hand, it is a site of isolation, of misery, of violence, and discrimination. This paradox is easily perceived in these two films since they both depict the city as the locus of permanent social disequilibrium, but also as the scenario of unexpected encounters and alliances, like those between Elizabeth and Ousmane, or among Will, Miro and Amira.

The two films evidence that postcolonial cities are the sites of capitalism, imperialism and globalization, but they are also the sites from which to resist and contest those forces. Neither of these two directors falls easily into the unproblematic Rushdiesque celebration of hybridity and multicultural encounter, but they reveal, through those unpredictable alliances (cultural, racial, religious, generic or generational) the postcolonial city's potential for stimulating interaction. Actually, as John Clement Ball (2004: 244) argues, the new and unexpected are an essential part of the city's protean life: «History in its various forms has a habit of bursting forth unexpectedly, generating new and transforming stories for the city in the form of surfacing Roman baths or phantasmagoric dreams or déjà- $v u$ architecture or grim race riots»».

Through the postcolonial reading of these films I have tried to prove to what an extent racial and social strata vertebrates the life of the city in multiple and complex ways, thus evidencing that cosmopolitan postmodern cultures are more fragmented, chaotic and unevenly developed formations than the simplistic versions of the multicultural myth would suggest. If, to put it into Neera Chandoke's (1991: 2868) terms, «the postcolonial city responds to the logic of accumulation and social struggles», the London featured by Minghella and Bouchareb stands as an eloquent example of this new urban identity that resists the utopia of a White Europe and bespeaks instead transnational geopolitics and its collateral effects. In this context, London emerges, once again, as a colossal, post-imperial city containing stories of survival and random-like encounters which explore the fantasies and fears about otherness and where their protagonists contest racialized stereotypes and cliché notions of cultural diversity. Their tragic testimonies proclaim that the postcolonial city is by no means an idealized, cheerfully hybrid and polyglot space beyond the conflicts of our global present; and yet, despite the evidence of such conflicts, these stories provide the vision of transcultural engagement articulated with the dual language of pain and possibility, fatalism and utopia. 


\section{Works Cited}

AbBas, T. (2005): «British South Asian Muslims: Before and After September 11» in ABbas, T. (ed.) Muslim Britain: Communities under Pressure, London, Zed Books.

BALL, J. C. (2004): Imagining London: Postcolonial Fiction and the Transnational Metropolis, Toronto, Toronto UP.

BIRD, L.; N. LuKA (2010): "Arts of (Dis)placement: City Space and Urban Design in the London of Breaking and Entering», Cinémas: Journal of Film Studies, 21 (1): 179-103.

Bouchareb, R. Dir. (2009): London River, Arte France \& 3B Productions.

Brunsdon, C. (2007): London in Cinema: The Cinematic City since 1945, London, British Film Institute.

Chambers, I. (1994): Migrancy, Culture, Identity, London \& New York, Routledge.

Chandoke, N. (1991): «The Postcolonial City», Economic and Political Weekly, 26 (50): 2868-2873.

Dizdar, J. Dir. (1998): Beautiful People, British Film Institute \& Trimark Pictures.

GiKANDI, S. (1996): Maps of Englishness: Writing Identity in the Culture of Colonialism, New York, Columbia UP.

GILroy, P. (1999): «A London sumting dis...», Critical Quarterly, 41 (3): 57-69.

HaIn, M. (2012): «Interview with Charlotte Brunsdon». $<$ http://25fps.cz/2012/cinematic-london>.

Hyde, M. (2012): «Olympic Games opening ceremony: irreverent and idiosyncratic», The Guardian, Saturday 28 July, 2012.

$<$ http://www.guardian.co.uk/sport/2012/jul/28/olympic-games-openingceremony-british>.

Kelly, A.; A. Street (2009): «Public Opinion and the 2005 London Transit Bombings», Paper presented at the Annual Meeting of the American Political Science Association, Toronto, September 3, 2009.

$<$ http://www.alexstreet.net/papers/ASAK_paper_AS_Dec_4.pd>.

MaLIK, S. (2002): Representing Black Britain: A History of Black and Asian Images on British Television, London, Sage.

Mazierska, E.; L. Rascaroli (2003): From Moscow to Madrid: Postmodern Cities, European Cinema, London and New York, IB Tauris.

MCLeOD, J. (2004): Postcolonial London: Rewriting the Metropolis, London, Routledge.

Minghella, A. Dir. (2006): Breaking and Entering, Miramax.

N'Diaye, C. (1984): Gens de sable, Paris, Editions POL. 
Rose, D. (1984): «Rethinking Gentrification: Beyond the Uneven Development of Marxist Urban Theory», Environment and Planning D: Society and Space, 1: 47-74.

SANDHU, S. (2003): London Calling: How Black and Asian Writers Imagined a City, London, Harper Collins.

Slater, T. (2011): «The Gentrification of the City» in BRIdGe, G.; S. Watson (eds.) (2011): The New Blackwell Companion to the City, London, Blackwell. 